\title{
Politik Hukum Ekonomi Pertahanan di Indonesia Tahun 2002-2018 : Kajian Industri Pertahanan.
}

\section{Politics of Defense Economic Law in Indonesia in 2002-2018 : Defense Industry Study}

\author{
Endro Tri Susdarwono \\ FISIP Universitas Peradaban Bumiayu \\ saniscara99midas@gmail.com \\ Telp. 0812-292-722-96
}

\begin{abstract}
ABSTRAK
Penelitian ini membahas tentang politik hukum ekonomi pertahanan di Indonesia tahun 2002-2018 untuk kajian industri pertahanan. Kajian studi ekonomi pertahanan dikaji tidak hanya dari wacana ekonomi tetapi dari wacana hukum dan politik. Industri pertahanan merupakan salah satu komponen vital dari kemampuan pertahanan. Industri pertahanan yang kuat mempunyai dua efek utama, yakni efek langsung terhadap pembangunan kemampuan pertahanan, dan efek terhadap pembangunan ekonomi dan teknologi nasional. Rencana induk pengembangan industry pertahanan merupakan penjabaran dari undang-Undang Industri Pertahanan yang menekankan adanya pemberian insentif untuk mendorong perkembangan industry pertahanan di Indonesia.
\end{abstract}

Kata Kunci : politik hukum; ekonomi pertahanan; industri pertahanan;

\begin{abstract}
This study discusses the legal politic of defense economics in Indonesia in 2002-2018 for the defense industry study. The study of defense economic studies is examined not only from economic discourse but from legal and political discourse. The defense industry is one of the vital components of defense capability. A strong defense industry has two main effects, namely the direct effect on the development of defense capabilities, and the effect on national economic and technological development. The master plan for developing the defense industry is an elaboration of the Defense Industry Law which emphasizes the provision of incentives to encourage the development of the defense industry in Indonesia.
\end{abstract}

Keyword : the political of law, defense economic, defense industry

\section{PENDAHULUAN}

\section{A. LATAR BELAKANG MASALAH}

Penelitian ini membahas tentang politik hukum ekonomi pertahanan di Indonesia tahun 2002-2018 untuk kajian industri pertahanan. Kajian studi ekonomi pertahanan dikaji tidak hanya dari wacana ekonomi tetapi dari wacana hukum dan politik.

Hukum dan politik seperti dua sisi mata uang, jika dibalik-balik pun akan memiliki nilai sama meski dalam perwajahan berbeda antara kedua sisinya. Seringkali hukum disebut sebagai 
manifestasi kebijakan publik yang sangat dipengaruhi oleh isu-isu politik. Dalam bab ini hendak ditampilkan sisi lain dari pada hukum, yaitu hukum sebagai instrument politik (law as political instrument) atau politik (kekuasaan) sebagai alat hukum (politics as legal instrument). Untuk maksud tersebut, maka titik berat atau fokus kajian adalah pada masalah hubungan hukum dan politik dengan segala aspeknya. Dengan demikian, diharapkan akan tergambar secara jelas benang merah (titik taut) yang menunjukkan kedekatan (kohesivitas) antara hukum dan politik.

Bagian yang substansial dari politik hukum terletak di bidang studi mengenai teknikteknik perundang-undangan. Kecuali interdisiplineritas dalam arti pendekatan yang dipakai, studi tentang politik hukum ini juga membutuhkan sedikit banyak penguasaan bidang-bidang di dalam sistem hukum itu sendiri. Penguasan ini terutama menyangkut asas-asas yang terdapat pada masing-masing bidang hukum tersebut. ${ }^{1}$

Ekonomi Pertahanan merupakan ranah disiplin ilmu bercorak multidisiplin. Pemaknaan Ekonomi Pertahanan pun bergerak mengikuti dinamika zaman dan tantangan global yang dihadapi dunia. Ekonomi Pertahanan pasca perang dingin tidak lagi sekedar bagaimana mengelola sumber daya logistik pada masa perang, mengelola pasokan persenjataan di medan perang atau strategi pemenangan perang dengan penguasaan sumber daya ekonomi. Pemahaman Ekonomi Pertahanan masa kini telah bergeser kepada persoalan-persoalan seperti konflik, terorisme, perdamaian, bencana hingga persoalan-persoalan sosial mulai dari pangan hingga kesehatan. Dari sudut pandang istilah, Ekonomi Pertahanan seperti halnya sifat dasar dari disiplin ilmu ekonomi yakni usaha atau aktivitas yang dilakukan dengan batasan-batasan seperti kelangkaan (scarsity), isu alokasi sumber daya optimal, ketidak sempurnaan informasi, utilisasi, insentif dan pencapaian titik optimum dari keseluruhan sumber daya yang dimiliki.

Industri pertahanan terutama defense offset juga merupakan kajian dalam ekonomi pertahanan. Defense Offset adalah proses pembelian atau investasi timbale balik yang disepakati oleh produsen atau pemasok persenjataan sebagai imbal dari kesepakatan pembelian jasa dan barang-barang militer. Praktik Defense offset dalam pengadaan alat pertahanan memberikan satu perspektif bahwa transfer teknologi pertahanan yang didukung mekanisme Defense Offset harus ditopang dengan kesiapan sumber daya manusia, anggaran, bahan baku,

\footnotetext{
${ }^{1}$ Satjipto Rahardjo, Ilmu Hukum (Bandung : PT Citra Aditya Bakti, 2012), halaman 399.
} 
serta lembaga penelitian dan pengembangan yang dapat memudahkan proses alih teknologi tersebut sehingga mampu memenuhi kebutuhan alat pertahanan. ${ }^{2}$

Industri pertahanan seyogyanya adalah concern kita bersama, para pemangku kepentingan di segala lini. Pihak pemerintah, selain menghasilkan regulasi dan menjadi pendukung atau endorser, punya kontribusi vital dalam pengembangan industri pertahanan karena perannya yang luas sebagai pengguna produk-produk industri pertahanan. ${ }^{3}$

Di pihak lain, kalangan industri pertahanan dan masyarakat secara umum - misal pusatpusat studi, universitas, serta lembaga non pemerintah- juga memegang peran yang cukup besar dalam mengembangkan industri pertahanan. Belajar dari Negara-negara yang memiliki industri pertahanan yang sudah maju, well advanced, bisa kita pahami bagaimana konseptualisasi hubungan pemerintah-industri-masyarakat ikut mempengaruhi tren pertumbuhan ekonomi.

Berdasarkan latar belakang di atas, maka peneliti bermaksud untuk melakukan penelitian tentang Politik Hukum Ekonomi Pertahanan di Indonesia Tahun 2002-2018 : Kajian Industri Pertahanan.

\section{B. RUMUSAN MASALAH}

Berdasarkan paparan di atas, penelitian ini berusaha untuk mencari jawaban atas pertanyaan : bagaimana Politik Hukum Ekonomi Pertahanan di Indonesia Tahun 2002-2018 Kajian Industri Pertahanan. Secara lebih operasional, permasalahan penelitian ini dirumuskan sebagai berikut :

1. Bagaimana Politik Hukum Industri Pertahanan di Indonesia Tahun 2002-2007?

2. Bagaimana Politik Hukum Industri Pertahanan di Indonesia Tahun 2008-2014 ?

3. Bagaimana Politik Hukum Industri Pertahanan di Indonesia Tahun 2015-2018?

\section{TUJUAN PENELITIAN}

Berdasarkan pertanyaan-pertanyaan di atas, maka tujuan penelitian ini adalah :

1. Mengetahui politik hukum industri pertahanan di Indonesia tahun 2002-2007;

2. Mengetahui politik hukum industri pertahanan di Indonesia tahun 2008-2014;

3. Mengetahui politik hukum industri pertahanan di Indonesia tahun 2015-2018.

\section{MANFAAT PENELITIAN}

\section{1) Manfaat Teoretis}

\footnotetext{
${ }^{2}$ Muradi, Dinamika Politik Pertahanan dan Keamanan : Memahami Masalah dan Kebijakan Politik Pertahanan Keamanan Era Reformasi (Bandung : Widya Padjadjaran, 2012), halaman 115.

${ }^{3}$ Silmy Karima, Membangun Kemandirian Industri Pertahanan Indonesia (Jakarta : Kepustakaan Populer Gramedia, 2014), halaman x.
} 
Manfaat teoretis adalah manfaat penelitian bagi pengembangan ilmu pengetahuan sesuai dengan minat atau bidang kajian yang diteliti. Manfaat teoretis lebih ditekankan pada deskripsi tentang pengembangan konsep dan teori ekonomi pertahanan yang akan membantu para pemerhati untuk lebih memahami bidang kajiannya. Manfaat atau kegunaan penelitian menyatakan nilai yang dapat dipetik dari penelitian. Secara teoretis berguna sebagai upaya pengembangan ilmu pengetahuan, seperti upaya pengembangan wawasan keilmuwan peneliti, pengembangan teori ilmu ekonomi pertahanan, dan pengembangan bacaan bagi pendidikan ekonomi pertahanan.

\section{2) Manfaat Praktis}

Manfaat praktis adalah manfaat penelitian yang langsung dapat digunakan oleh masyarakat maupun pemerintah, khususnya di bidang ekonomi pertahanan. Dari segi praktis berguna sebagai upaya yang dapat dipetik langsung manfaatnya, seperti peningkatan keahlian meneliti dan keterampilan menulis, sumbangan pikiran dalam pemecahan suatu masalah, acuan pengambilan keputusan, dan bacaan baru bagi penelitian ekonomi pertahanan.

\section{TINJAUAN PUSTAKA}

\section{A. POLITIK HUKUM}

Secara teoretis hubungan hukum dengan politik/kekuasaan harusnya bersifat fungsional, artinya hubungan ini dilihat dari fungsi-fungsi tertentu yang dijalankan di antara keduanya. Terdapat fungsi timbal-balik antara hukum dengan kekuasaan, yaitu kekuasaan memiliki fungsi terhadap hukum, sebaliknya hukum juga memiliki fungsi terhadap kekuasaan. Per teori, ada tiga macam fungsi kekuasaan terhadap hukum :

1) Kekuasaan merupakan sarana membentuk hukum (law making), khususnya pembentukan peraturan perundang-undangan, baik dipusat maupun di daerah. Dalam kaitan ini Moh. Mahfud MD, mengatakan bahwa hukum merupakan produk politik di parlemen, sehingga materi muatan hukum merupakan "kompromi” kepentingan-kepentingan politik yang ada.

2) Kekuasaan merupakan alat menegakkan hukum. Penegakan hukum merupakan suatu proses mewujudkan keinginan hukum menjadi kenyataan. Yang dimaksud keinginan hukum adalah pikiran badan legislator yang dirumuskan dalam peraturan perundangan. Mochtar Kusumaatmadja berpendapat bahwa hukum tanpa kekuasaan akan lumpuh, kekuasaan tanpa hukum akan tirani/anarki.

3) Kekuasaan sebagai media mengeksekusi putusan hukum, putusan pengadilan yang berkekuatan hukum tetap, tidak akan banyak memiliki arti bagi pengorganisasian 
kehiduapan masyarakat tanpa adanya pelaksanaan (execution) seccara konsekuen dan konsisten. Dalam konteks ini hukum membutuhkan kekuasaan untuk mengakkannya.

Begitu juga sebaliknya, terdapat 3 (tiga) macam fungsi hukum terhadap kekuasaan :

1) Hukum sebagai media melegalisasi kekuasaan

Legalisasi hukum terhadap kekuasaan berarti menetapkan keabsahan (validity) kekuasaan dari aspek yuridisnya. Setiap kekuasaan yang memiliki landasan hukum secara formal, berarti memiliki legalitas. Yang menjadi masalah adalah jika kekuasaan yang dilegalisasi oleh hukum tersebut bersifat sewengan-wengan atau tidak adil. Hal ini secara sosiologik, berkaitan erat dengan apa yang disebut legitimasi kekuasaan, yaitu pengakuan masyarakat terhadap keabsahan hukum. Artinya meskipun sebuah kekuasaan telah mendapat legalisasi secara yuridis formal, akan tetap jika masyarakat berpandangan bahwa kekuasaan tersebut bersifat sewengan-wenang dan tidak sesuai dengan rasa keadilah masyarakat, maka kekuasaan yang demikian tetap tidak akan mendapatkan legitimasi/pengakuan dari masyarakat. Hal ini seperti dikatakan oleh penganut tokoh kedaulatan hukum Hugo The Grabbe bahwa " tidak dapat disebut sebagai hukum, jika tidak mencerminkan nilai-nilai keadilan masyarakat, meskipun hal tersebut telah dituangkan dalam bentuk tertulis dalam peraturan perundang-undangan."

2) Hukum Berfungsi Mengatur dan Membatasi Kekuasaan

Hukum tidak hanya membatasi kekuasaan, tetapi ia juga mengatur dan memberikan kekuasaan kepada orang-orang. Dengan demikian, maka hukum itu merupakan sumber kekuasaan, oleh karena itu melalui hukum, kekuasaan itu dibagi-bagikan dalam masyarakat. Kekuasaan yang diatur oleh hukum, merupakan kekuasaan yang dibatasi, baik isi, ruang lingkup, prosedur memperolehnya, kesemuanya ditentukan oleh hokum. Pembatasan kekuasaan oleh hukum dimaksudkan untuk menghindari terjadinya penumpukan atau sentralisasi kekuasaan pada satu tangan atau satu lembaga. Sebab, sentralisasi kekuasaan akan mendorong kepada otoritarianisme dalam penyelenggaraan Negara atau penyalahgunaan kekuasaan (abuse of power).

3. Hukum Berfungsi Meminta Pertanggung-jawaban Kekuasaan

Pertanggungjawaban kekuasaan dalam konteks hukum adalah menjaga agar penggunaan kekuasaan sesuai dengan mekanisme dan tujuan pemberian kekuasaan tersebut. Penyalahgunaan kekuasaan oleh pejabat Negara dalam bidang hukum administrasi dapat dilakukan melalui proses Peradilan Tata Usaha Negara (PTUN), penyalahgunaan kekuasaan oleh penyelenggara Negara yang merugikan kepentingan masyarakat dapat digugat melalui 
peradilan umum (perdata), sedangkan penyalahgunaan kekuasaan yang masuk kategori tindak pidana dapat dituntut secara pidana. ${ }^{4}$

\section{B. EKONOMI PERTAHANAN}

Bidang ekonomi pertahanan berbeda dengan bidang ekonomi lain dalam hal objek yang diteliti, aturan kelembagaan dari organisasi pertahanan, seperti tata cara pengadaan persenjataan, dan isu-isu yang diteliti. Michael D. intriligator (1990) menjelaskan bahwa isuisu yang terkait dengan ekonomii pertahanan, antara lain tingkat belanja perthanan, dampak pengeluaran pertahanan terhadap produk dan lapangan kerja di dalam dan luar negeri, pertimbangan mengenai eksistensi dan besaran lingkup pertahanan, kaitan antara belanja pertahanan dengan perubahan teknologi, dan implikasi belanja pertahanan dalam lingkup pertahanan dalam rangka kestabilan atau ketidakstabilan internasional. ${ }^{5}$

Hasil kegiatan pertahanan adalah barang public murni, karena bersifat noneksklusif dan nonrivalitas. Nonekslusif yaitu memberikan manfaat bagi semua warga negara tanpa kecuali. Manfaat dari hasil kegiatan ini dapat dikatakan sebagai tidak kasat mata (intangible). Nonrivalitas yaitu konsumsi tambahan dapat dimungkinan tanpa biaya marjinal. Penggunaan tambahan satu unit barang tersebut dapat dilakukan oleh setiap orang tanpa mengurangi kesempatan orang lain untuk mengonsumsi barang yang sama. Barang public seperti ini berbeda dengan barang privat, yang memberi manfaat hanya bagi orang-orang tertentu dan penggunakaan tambahan satu unit oleh seseorang akan mengurangi kesempatan orang lain untuk mengonsumsi barang tersebut.

Ekonomi pertahanan terkait erat dengan kedua sector ekonomi (mikro dan makro), baik moneter, maupun fiscal. Dalam banyak hal, pembiayaan pertahahanan dilakukan dengan menggunakan anggaran belanja pemerintah (on-government balance sheet). Pembiayaan dapat langsung menggunakan alokasi anggaran tahunan pemerintah atau menggunakan dana pinjaman yang dapat berasal dari dalam atau luar negeri. Adakalanya pembiayaan dilakukan dengan menerbitkan surat piutang yan akan menjadi beban anggaran belanja pemerintah apabila digunakan anggaran belanja langsung dari pemerintah, maka akan memengaruhi sisi pengeluaran tahunan pemerintah. Namun, apabila dengan menggunakan pinjaman, makan akan berpengaruh terhadap neraca pembayaran pemerintah, lebih khusus lagi neraca modal. Dalam

\footnotetext{
${ }^{4}$ Raharjo, op.cit., halaman 147-148.

${ }^{5}$ Purnomo Yusgiantoro, Ekonomi Pertahanan : Teori dan Praktik (Jakarta : Gramedia Pustaka Utama, 2014), halaman 5.
} 
perkembangannya, berbagai masalah ekonomi pertahanan menggunakan solusi dengan pendekatan kuantitatif, baik itu pendektan riset operai (Operation Research System Analysis/ORSA), simulai numerik, maupun statistic. ${ }^{6}$

Komponen utama Ilmu Ekonomi Pertahanan antara lain, pertama adalah kebijakan dan strategi pertahanan yang terkait dengan pembangunan, penggunaan, dan pembinaan kekuatan pertahanan negara. Kedua, perencanaan pertahanan yang terkait dengan pembangunan kekuatan penangkal (deterrent power) untuk mencegah ancaman, dan yang ketiga, industry pertahanan yang terkait dengan produksi peralatan perthanan untuk menghasilkan nilai tambah dan efek penggandaan (multiplier effect) dalam perekonomian. Selanjutnya yang keempat adalah perhitungan optimalisasi dalam penggunaan sumberdaya. Ekonomi pertahanan mempunyai lingkup yang luas stidak hanya terbatas pada empat komponen tersebut, tetapi menyangkut juga masalah konflik, kerjasama pertahanan, perdagangan internasional, pembiayan, dan pengadaan pertahanan. Komponen-komponen utama tersebut masih dapat diperinci yang memungkinkan adanya pengembangan ekonomi pertahanan untuk merefleksikan isu terkini yang dihadapi oleh masyarakat atau suatu negara. Sebagai contoh, dengan berkembangnya konflik nontradisional yang antara lain terorrisme, penggunaan CBRN-E (Chemical, Biology, Radiation, Nuclear and Explosive) dan cyber akan memperlebar lingkup dari ekonomi pertahanan.

\section{INDUSTRI PERTAHANAN}

Secara umum industry Pertahanan dapat didefinisikan sebagai tempat pertemuan antara produsen dengan konsumen produk pertahanan beserta industry penunjangnya. Pasar sebagai tempat pertemuan tersebut terkadang memerlukan rantai penghubung seperti agen, distributor, eksportir dan importir. Penunjang industry pertahanan, di sau sisi diperlukan untuk memenuhi factor produksi dan di sisi lain produk industry pertahann untuk mendukung keberadaan industry lainnya. Dalam industry pertahanan, pasar monopoli, oligopoly, dan kompetitif banyak dipengaruhi oleh factor internal dan eksternal perusahaan. ${ }^{7}$

Factor internal :

1. Factor produksi yang terkait erat dengan biaya mampu menghasilkan barang dan jasa pada skala keekonomiannya, dan menurunkan biaya produksi dari produsen lain, sehingga berperilaku sebagai monopoli alamiah.

\footnotetext{
${ }^{6}$ Ibid, halaman 14.

${ }^{7} \mathrm{Ibid}$, halaman 176.
} 
2. Factor tugas dari perusahaan lain atau dari perusahaan induk atau adanya merger dengan perusahaan dominan dalam pasar oligopoly, menyebaban suatu produsen menguasai beberapa factor produksi utama.

3. Factor kompetisi dengan perusahaan-perusahaan pesaing melalui penciptaan hambatan, antara lain dalam penguasaan penjualan produk dengan penurunan harga yang sangat rendah, sehingga sulit disaingi

Factor eksternal. ${ }^{8}$ :

1. Factor kepentingan mengendalikan kapasitas produksi dan memberikan perlindungan atau proteksi, pemerintah dalam pemberian hak monopoli kepada satu produsen tertentu untuk memproduksi barang public.

2. Factor perolehan hak paten oleh suatu perusahaan memungkinkan perusahaan tersebut berperilaku monopoli. Pada umumnya, suatu negara memberikan hak paten yang dilindungi oleh undang-undang.

3. Factor izin konsesi yang diberikan pemerintah kepada suatu perusahaan untuk mengoperasikan pelayanan atau kegiatan tertentu.

Pemerintah mempunyai peranan penting dalam membangun industry pertahanan, karena pemerintah merupakan pembeli yang besar atau pembeli tunggal dari peralatan pertahanan yang diproduksi di dalam negeri (monopsoni). Pemerintah dapat menggunakan daya belinya untuk menentukan besaran, kepemilikan, struktur, proses masuk dan keluar, produk, harga, tingkat efisiensi, dan bahkan profitabilitas industry pertahanan nasional (baik BUMN maupun BUMS). Pemerintah sangat mendukung industry pertahanan, antara lain dengan cara pembelian khusus melalui pemberian subsidi langsung. Pemerintah juga dapat mengatur industry pertahanan nasional dengan mengendalikan keuntungan pada kontrak pemerintah (misalnya mencegah keuntungan atau kerugian yang berlebihan). Selain itu, pemerintah juga termasuk dapat menentukan harga dan keuntungan dari kontrak nonkompetitif, sehingga dapat memengaruhi perilaku perusahaan dengan memihak persainan non harga (peneitian dan pengembangan), dan dapat mengontrol ekspor senjata, misalnya melalui lisensi. ${ }^{9}$

\section{METODE PENELITIAN}

Penelitian ini termasuk penelitian hukum normatif yang hanya menggunakan data sekunder. Tipe penelitian hukumnya adalah kajian komprehensif analitis terhadap bahan

\footnotetext{
${ }^{8}$ Ibid, halaman $176-177$.

${ }^{9} \mathrm{Ibid}$, halaman $185-186$.
} 
hukum primer dan bahan hukum sekunder. Hasil kajian dipaparkan secara lengkap, rinci, jelas, dan sistematis sebagai karya ilmiah

\section{A. Metode Pendekatan}

Metode pendekatan yang digunakan adaah metode pendekatan yuridis normatif. Karena penelitian ini termasuk penelitian hukum normatif, pendekatannya menggunakan pendekatan normatif analitis, dengan mengikuti langkah-langkah sebagai berikut :

1) mengidentifikasi sumber hukum yang menjadi dasar rumusan masalah;

2) mengidentifikasi pokok bahasan dan subpokok bahasan yang bersumber dari rumusan masalah;

3) mengidentifikasi dan menginventarisasi ketentuan-ketentuan normatif bahan hukum primer dan bahan hukum sekunder berdasarkan rincian subpokok bahasan;

4) mengkaji secara komprehensif analitis bahan hukum primer dan bahan hukum sekunder guna menjawab permasalahan yang telah dirumuskan;

5) hasil kajian sebagai jawaban permasalahan dideskripsikan secara lengkap, rinci, jelas, dan sistematis dalam bentuk laporan hasil penelitian atau karya tulis ilmiah.

\section{B. Spesifikasi Penelitian}

Spesifikasi penelitian dalam penelitian ini menggunakan deskriptif analitis, yaitu menguraikan hasil-hasil penelitian sesuai dengan permasalahan dan tujuan yang akan dicapai serta menganalisanya dari segi peraturan perundangan yang berlaku.

\section{Teknik Penentuan Sampel}

Dalam penelitian ini menggunakan penetapan sampel dengan cara nonprobabilitas sampling atau nonrandom sampling dengan pengambilan sampel secara purposive sampling disesuaikan dengan tujuan penelitian. Ukuran sampel tidak dipersoalkan. Sampel yang diambil hanya yang sesuai dengan tujuan penelitian. Dengan kata lain, sampel yang dihubungi adalah sampel yang sesuai dengan kriteria tertentu yang ditetapkan berdasarkan tujuan penelitian.

\section{Teknik Pengumpulan Data}

Dalam penelitian hukum normatif dikenal 3 (tiga) jenis metode pengumpulan data sekunder, yaitu:
a. studi pustaka ( bibliography study);
b. dokumen (document study); dan
c. studi arsip (file or record study)

\section{E. Analisa Data}


Analisis data (analyzing), yaitu menguraikan data dalam bentuk kalimat yang baik dan benar, sehingga mudah dibaca dan diberi arti (diinterpretasikan) sehingga hasil analisis data memudahkan pengambilan kesimpulan secara induktif.

Bahan hukum (data) hasil pengolahan tersebut dianalisis secara kualitatif dan kemudian dilakukan pembahasan. Berdasarkan hasil pembahasan kemudian diambil kesimpulan sebagai jawaban terhadap permasalahan yang diteliti.

\section{HASIL DAN PEMBAHASAN}

A. POLITIK HUKUM INDUSTRI PERTAHANAN DI INDONESIA TAHUN 20022007

\section{A.1.Peraturan Perundang-undangan yang terkait sebagai Landasan Operasional}

1) Undang-undang No.3 tahun 2002 tentang Pertahanan Negara.

a) Pada Bab V tentang Pembinaan Kemampuan Pertahanan pasal 20 ayat (2) menyatakan bahwa "Segala sumberdaya nasional yang berupa SDM, sumberdaya alam dan buatan, nilai-nilai, teknologi dan dana dapat didayaguna-kan untuk meningkatkan kemampuan pertahanan negara yang diatur lebih lanjut dengan peraturan pemerintah". Dalam ayat tersebut dapat diartikan bahwa teknologi sebagai salah satu sumber daya nasional, dapat didayagunakan untuk meningkatkan Pertahanan Negara.

b) Pasal 23 ayat (1): "Dalam rangka meningkatkan kemampuan pertahanan negara, pemerintah melakukan penelitian dan pengembangan industri dan teknologi di bidang pertahanan". Ayat (2) : "Dalam menjalankan tugas sebagaimana dimaksud dalam ayat (1), Menteri mendorong dan memajukan pertumbuhan Indhan".

2) Undang-undang no. 18 tahun 2002 tentang Sistem Nasional Penelitian, Pengembangan dan Penerapan Ilmu Pengetahuan dan Teknologi.

a) Pada pasal 4 menyebutkan "Sistem Nasional Penelitian Pengembang-an dan Penerapan Iptek bertujuan memperkuat daya dukung Iptek bagi keperlu-an mempercepat pencapaian tujuan Negara, serta meningkatkan daya saing dan kemandirian memperjuangkan kepentingan Negara dalam pergaulan Internasional".

Dengan memahami pasal ini maka Litbang Indhan sebagai salah satu lembaga yang dimaksud dalam Undang-undang tersebut untuk mempercepat pencapaian tujuan Negara, meningkatkan daya saing dan kemandirian sesuai yang dimaksud pada pasal tersebut.

b) Pasal 15 ayat (2):".... Perguruan Tinggi, lembaga Litbang, badan usaha dan lembaga penunjang wajib mengusahakan kemitraan dalam hubungan yang saling mengisi, melengkapi, memperkuat dan menghindarkan terjadinya tumpang-tindih yang merupakan pemborosan".

Pasal tersebut mengisyaratkan untuk mendapatkan hasil Litbang yang optimal antara unsur-unsur Litbang perguruan tinggi, lembaga Litbang, Litbang badan usaha (R \& D) dan lembaga-lembaga lain yang terkait diwajibkan untuk menjalin kerjasama Litbang, sehingga diharapkan dapat menghasilkan temuan atau inovasi teknologi yang unggul.

c) Pasal 27 ayat (3): "Perguruan Tinggi, lembaga Litbang, badan usaha, lembaga penunjang, organisasi masyarakat dan inventor mandiri berhak atas dukungan dana dari anggaran Pemerintah dan Pemerintah Daerah untuk meningkatkan penguasaan, pemanfaatan dan pemajuan Iptek sesuai dengan peraturan perundang-undangan".

(Tim Puslitbang Indhan Balitbang Dephan)

\section{A.2 Buku Putih Pertahanan Negara Republik Indonesia Tahun 2003 Kementerian Pertahanan}


Kerjasama Dephan dan TNI dengan lembaga-lembaga lain merupakan bagian penting dari kebijaksanaan Strategis Pertahanan. Sesuai UU Nomor 3 Tahun 2002, kerjasama tersebut dilaksanakan dalam rangka pembinaan teknologi dan industri pertahanan yang diperlukan TNI dan Komponen pertahanan lainnya. Kerjasama dimaksud memiliki nilai strategis, karena dapat mendorong percepatan menuju kemandirian nasional di bidang teknologi pertahanan, termasuk memberi ruang bagi sektor lain untuk terlibat dalam penyelenggaraan pertahanan negara.

\section{B. POLITIK HUKUM INDUSTRI PERTAHANAN DI INDONESIA TAHUN 2008- 2014}

B.1 Buku Putih Pertahanan Indonesia Tahun 2008 Departemen Pertahanan Republik Indonesia.

Industri pertahanan merupakan salah satu komponen vital dari kemampuan pertahanan. Industri pertahanan yang kuat mempunyai dua efek utama, yakni efek langsung terhadap pembangunan kemampuan pertahanan, dan efek terhadap pembangunan ekonomi dan teknologi nasional. Dalam bidang pembangunan kemampuan pertahanan, industri pertahanan yang kuat menjamin pasokan kebutuhan Alutsista dan sarana pertahanan secara berkelanjutan. Ketersediaan pasokan Alutsista secara berkelanjutan menjadi prasyarat mutlak bagi keleluasaan dan kepastian untuk menyusun rencana pembangunan kemampuan pertahanan dalam jangka panjang, tanpa adanya kekhawatiran akan faktor-faktor politik dan ekonomi, seperti embargo atau restriksi. Industri pertahanan dapat memberikan efek pertumbuhan ekonomi dan industri nasional, yakni ikut menggairahkan pertumbuhan industri nasional yang berskala internasional, penyerapan tenaga kerja dalam jumlah yang cukup signifikan, transfer teknologi yang dapat menggairahkan sektor penelitian, dan pengembangan sekaligus memenuhi kebutuhan sektor pendidikan nasional di bidang sains dan teknologi.

Dalam rangka pengembangan industri pertahanan, Departemen Pertahanan akan menyusun kebijakan pembinaan teknologi dan industri pertahanan untuk memenuhi kebutuhan pertahanan negara. Untuk mewujudkan sasaran tersebut, Departemen Pertahanan akan melibatkan pihak di dalam negeri, meliputi perguruan tinggi, sektor swasta, maupun dengan Badan Usaha Milik Negara, BPPT, TNI, atau lembaga lain yang memiliki kemampuan dalam bidang sains dan teknologi.

\section{B.2 Risalah Rapat Kerja Komisi I DPR RI dengan Menteri Pertahanan dan Panglima TNI Tahun Sidang 2009-2010 Masa Persidangan II Senin, 22 Februari 2010}

Risalah ini memuat tentang pembahasan konsep pembentukan Komite Kebijakan Industri Pertahanan dan Masterplan industri pertahanan : 
“...Pada MoU antara Menteri Pertahanan, Menteri Negara BUMN, dan Panglima TNI dan Kapolri tentang revitalisasi industri pertahanan dalam negeri, pada tanggal 11 Desember 2009 yang lalu, berisikan kesepakatan untuk pemesanan alutsista dari industri dalam negeri selama 1 renstra 5 tahun. Jadi kita sudah menyerahkan kebutuhan selama 5 tahun alutsista kepada BUMNIS, hal tersebut sebagai jaminan pada industri pertahanan dalam memproduksi alutsista secara konsisten dan berkelanjutan guna mencapai skala keekonomian yang diharapkan..."

\section{B.3 Peraturan Presiden Nomor 42 Tahun 2010 Tentang Komite Kebijakan Industri}

\section{Pertahanan (KKIP)}

Komite Kebijakan Industri Pertahanan yang selanjutnya disingkat KKIP adalah komite yang mewakili Pemerintah untuk mengoordinasikan kebijakan nasional dalam perencanaan, perumusan, pelaksanaan, pengendalian, sinkronisasi, dan evaluasi Industri Pertahanan. Pemerintah membentuk Komite Kebijakan Industri Pertahanan (KKIP). KKIP terdiri dari Menteri Pertahanan, Meneg BUMN,Presiden membentuk KKIP untuk mengoordinasikan kebijakan nasional dalam perencanaan, perumusan, pelaksanaan, pengendalian, sinkronisasi, dan evaluasi Industri Pertahanan. KKIP berkedudukan di ibu kota Negara Kesatuan Republik Indonesia.

\section{B.4. Risalah Rapat Dengar Pendapat (RDP) Panitia Kerja (Panja) RUU Tentang Industri Pertahanan dan Keamanan Komisi I DPR RI}

Pembahasan tentang penting dan tujuan utama dari UU Industri Pertahanan

“...Tujuan utama daripada UU Industri Pertahanan ini adalah bagaimana kita untuk menghasilkan kemandirian industri pertahanan dalam rangka mengisi kekosongan untuk peralatan Alutsista bagi TNI dan Polri. Oleh karena itu, semua sumberdaya nasional yang dapat dimanfaatkan untuk tujuan tersebut, seperti permodalan, Sumber Daya Manusia, teknologi, dan sarana/prasarana infrastruktur dapat digunakan, dapat dimanfaatkan, dapat dialokasikan melalui UU ini untuk mencapai tujuan yang kita harapkan..."

Dari hasil perbandingan beberapa negara akhirnya diusulkan bahwa model yang sesuai dengan posisi daripada industry pertahanan di Indonesia yang diusulkan kepada DPR adalah bawah Presiden membawahi TNI, Kemhan, dan KKIP. KKIP terdiri dari unsur-unsur Kementerian Pertahanan, Kementerian Perindustrian, Kementerian BUMN, dan nantinya akan dimasukan Kemenkeu. Kemenhan secara teknis membina industri pertahanan, terdiri dari BUMN dan BUMS, sedangkan KKIP akan melakukan koordinasi terhadap industri pertahanan yang teknis dibina oleh Kemhan, sedangkan nanti mengenai corporate-nya tetap di bawah Kementerian BUMN.

\section{B.5 Undang-Undang Nomor 16 Tahun 2012 Tentang Industri Pertahanan}

Industri Pertahanan sebagaimana berada di bawah pembinaan Pemerintah yang dikoordinasikan oleh KKIP. Industri Pertahanan sebagaimana dimaksud dalam Pasal 9 Undang-Undang Nomor 16 Tahun 2012 meliputi: 
a. industri alat utama;

b. industri komponen utama dan/atau penunjang;

c. industri komponen dan/atau pendukung (perbekalan); dan

d. industri bahan baku.

Industri alat utama sebagaimana dimaksud merupakan badan usaha milik negara yang ditetapkan oleh Pemerintah sebagai pemadu utama (lead integrator) yang menghasilkan alat utama sistem senjata dan/atau mengintegrasikan semua komponen utama, komponen, dan bahan baku menjadi alat utama.

Industri komponen utama dan/atau penunjang sebagaimana dimaksud merupakan badan usaha milik negara dan/atau badan usaha milik swasta yang memproduksi komponen utama dan/atau mengintegrasikan komponen atau suku cadang dengan bahan baku menjadi komponen utama Alat Peralatan Pertahanan dan Keamanan dan/atau wahana (platform) sistem alat utama sistem senjata.

Industri komponen dan/atau pendukung (perbekalan) sebagaimana dimaksud merupakan badan usaha milik negara dan/atau badan usaha milik swasta yang memproduksi suku cadang untuk alat utama sistem senjata, suku cadang untuk komponen utama, dan/atau yang menghasilkan produk perbekalan.

Industri bahan baku sebagaimana dimaksud merupakan badan usaha milik negara dan badan usaha milik swasta yang memproduksi bahan baku yang akan digunakan oleh industri alat utama, industri komponen utama dan/atau penunjang, dan industri komponen dan/atau pendukung (perbekalan). Perencanaan penyelenggaraan Industri Pertahanan yang bersifat strategis disusun oleh KKIP dengan mengakomodasikan kepentingan Pengguna dan Industri Pertahanan.

\section{B.6 Peraturan Presiden Republik Indonesia Nomor 59 Tahun 2013 Tentang Organisasi, Tata Kerja dan Sekretariat KKIP}

Peraturan Presiden RI Nomor 59 tahun 2013 tentang Organisasi, Tata Kerja, dan Sekretariat KKIP membawa arah kebijakan industry pertahanan RI semakin jelas dan terkontrol karena idealnya telah dibuat suatu blue print bagaiamana sebenarnya pengembangan industry pertahanan ke depan telah dibuat, tentunya dengan berbagai pertimbangan dan analisis yang mendalam, tentunya dengan membuat suatu kerangka kerja atau framework of analysis untuk menentukan visi dan arah dari industry pertahanan kita.

\section{POLITIK HUKUM INDUSTRI PERTAHANAN DI INDONESIA TAHUN 2015- 2018}




\section{C.1 Buku Putih Pertahanan Indonesia Tahun 2015 Kementerian Pertahanan Republik Indonesia}

Pengembangan teknologi industri pertahanan diarahkan untuk membangun kemampuan untuk menghasilkan Alpalhankam yang memenuhi persyaratan operasional, yaitu memiliki kualitas tinggi, tahan cuaca, ketelitian-akurasi, daya gempur dan kecepatan tinggi, sulit dideteksi dan keunggulan lainnya. Pengembangan industri pertahanan merupakan serangkaian kegiatan terhadap penguasaan teknologi guna mendukung terwujudnya sistem pertahanan negara yang tangguh, berdaya tangkal, modern, dan dinamis. Penguasaan teknologi industri pertahanan akan mengangkat posisi tawar dalam penguasaan teknologi pertahanan.

Pembinaan industri pertahanan merupakan bagian dari penyelenggaraan pertahanan secara utuh, dan bagian dari pembangunan secara menyeluruh. Pembinaan industri pertahanan nasional melibatkan pihak pengguna, produsen, dan pemerintah sebagai regulator yang dikoordinasikan dan disinergikan oleh KKIP. Kemhan bertekad untuk mengembangkan industri pertahanan di bidang daya gerak, daya tempur, daya dukung, dan bekal. Hal ini tertuang dalam kebijakan pembinaan industri pertahanan sebagai dasar hukum bagi perwujudan kemandirian pertahanan. Pembinaan ini merupakan langkah pengembangan kekuatan persenjataan yang mengarah kepada pemberdayaan industri pertahanan nasional untuk mencapai kemandirian pengadaan Alutsista.

Pengembangan industri pertahanan tidak terlepas dari skema kerja sama. Skema kerja sama yang saling menguntungkan merupakan salah satu kriteria industri pertahanan. Kerja sama diarahkan bagi percepatan peningkatan penguasaan teknologi pertahanan serta guna menekan biaya pengembangan teknologi. Kerja sama ini dilaksanakan antarindustri dalam negeri atau antara industri dalam negeri dan luar negeri dalam bidang pendidikan, pelatihan, alih teknologi, peneitian dan pengembangan, perekayasaan, produksi, pemasaran, dan pembiayaan.

\section{C.2 Keputusan Menteri Pertahanan Nomor : KEPI/1008/M/V/2017 Tentang Kebijakan Pertahanan Negara Tahun 2018}

Adapun pokok-pokok kebijakan pembangunan pertahanan negara dan pemberdayaan pertahanan negara dinyatakan bahwa:

- Pembangunan industry pertahanan, untuk membangun industri yang kuat, mandiri, dan berdaya saing agar mampu mendukung pemenuhan kebutuhan Alpalhan dan dukungan komponen dan peralatan pendukungnya termasuk perbaikan dan pemeliharaannya serta diversifikasi industri pertahanan yang dilaksanakan dengan: mendorong pembangunan 
struktur industri pertahanan dan kerjasama dengan industri pertahanan luar negeri; meningkatkan kemampuan teknologi dan kapabilitas industri pertahanan; dan pembinaan industri pertahanan secara terintegrasi dengan memperhatikan pengamanan teknologi melalui program K/L dalam lingkup Komite Kebijakan Industri Pertahanan (KKIP).

- Pemberdayaan industri pertahanan, guna pengembangan industri nasional menjadi industri pertahanan yang diarahkan pada: pemenuhan kebutuhan Alpalhan, mendorong dalam memproduksi produk-produk untuk kepentingan pertahanan dan non pertahanan, kerjasama dengan industri pertahanan luar negeri baik kerjasama produksi dan kerjasama pengembangan.

Arah kebijakan pertahanan negara tahun 2018 terkait dengan industry pertahanan ditentukan dengan mewujudkan industri pertahanan yang kuat, mandiri dan berdaya saing melalui peningkatan peran KKIP dalam merumuskan kebijakan nasional industri pertahanan.

Sasaran kebijakan pertahanan negara tahun 2018 yang terkait dengan industry pertahanan mencakup pengintegrasian pembangunan Industri Pertahanan dengan memperhatikan penguasaan ilmu pengetahuan dan teknologi serta transfer teknologi melalui kerjasama K/L terkait dalam lingkup Komite Kebijakan Industri Pertahanan (KKIP) guna mewujudkan industri pertahanan yang kuat, mandiri, dan berdaya saing; peningkatan pemberdayaan industri nasional penunjang industri pertahanan dalam negeri untuk memproduksi komponen utama dan/atau penunjang, industri komponen dan/atau pendukung (perbekalan), industri bahan baku serta pemeliharaan Alat Utama Sistem Senjata (Alutsista)/ Alpalhan guna meningkatkan kerjasama, penelitian dan pengembangan produk baru yang menunjang perekonomian nasional. Pengintegrasian ini dilakukan melalui upaya pemindahan kawasan industri pertahanan secara bertahap ke wilayah Lampung yang diawali dengan kajian dan survey lokasi.

\section{KESIMPULAN}

Pada awal tahun 2000 an sampai dengan 2010, konsentrasi pemerintah Indonesia adalah mengatasi krisis dan menangani masalah ekonomi terutama tingkat kesejahteraan rakyat yang mengalami degradasi karena krisis ekonomi yang terjadi. Baru pada pemerintahan 2010-2014 Kabinet Indonesia Bersatu II (KIB), industry pertahanan mulai dibangkitkan kembali seiring dengan rencana pemerintah untuk membangun kekuatan pertahanan yang dituangkan dalam rencana strategis (renstra) pembangunan kekuatan pokok Indonesia dalam lima belas tahun 
yang dibagi dalam tahapan tiap lima tahunan (Renstra I: 2010-2014, Renstra II : 2015-2019 dan Renstra III : 2020-2024).

Industri pertahanan merupakan salah satu komponen vital dari kemampuan pertahanan. Industri pertahanan yang kuat mempunyai dua efek utama, yakni efek langsung terhadap pembangunan kemampuan pertahanan, dan efek terhadap pembangunan ekonomi dan teknologi nasional. Dalam bidang pembangunan kemampuan pertahanan, industri pertahanan yang kuat menjamin pasokan kebutuhan Alutsista dan sarana pertahanan secara berkelanjutan.

Ketersediaan pasokan Alutsista secara berkelanjutan menjadi prasyarat mutlak bagi keleluasaan dan kepastian untuk menyusun rencana pembangunan kemampuan pertahanan dalam jangka panjang, tanpa adanya kekhawatiran akan faktor-faktor politik dan ekonomi, seperti embargo atau restriksi. Industri pertahanan dapat memberikan efek pertumbuhan ekonomi dan industri nasional, yakni:

- ikut menggairahkan pertumbuhan industri nasional yang berskala internasional,

- penyerapan tenaga kerja dalam jumlah yang cukup signifikan,

- transfer teknologi yang dapat menggairahkan sektor penelitian, dan

- pengembangan sekaligus memenuhi kebutuhan sektor pendidikan nasional di bidang sains dan teknologi.

Politik hukum pembangunan kembali industry pertahanan diawali dengan pembentukan Komite Kebijakan Industri Pertahanan (KKIP) melalui Peraturan Presiden Nomor 42 Tahun 2010. Dalam perjalanannya, selama hampir dua setengah tahun, KKIP yang bergerak pada tataran kebijakan industry pertahanan telah banyak menghasilkan cetak biru atau rencana induk dan program nasional yang diperlukan bagi pengembangan industry pertahanan. Dengan mempertimbangkan pentingnya industry pertahanan bagi pembangunan kekuatan pertahanan dan sebagai industry yang diharapkan nantinya mampu mendukung perekonomian nasional, maka ditetapkan Undang-Undang Nomor 16 Tahun 2012 tentang Industri Pertahanan.

Salah satu amanat Undang-Undang terseut adalah pembentukan KKIP yang kemudian dikukuhkan dengan Keppres nomor 59 tahun 2013. Dengan adanya undang-Undang industry Pertahanan tersebut, maka keberadaan KKP akan lebih jelas dalam mendukung pengembangan industry pertahanan Indonesia. Tugas KKIP sebagaimana diamanatkan dalam keppres Nomor 42 Tahun 2010 yang diperbaharui dengan Keppres Nomor 59 Tahun 2013 adalah menetapkan kebijakan industry pertahanan nasional pada tatarasan strategis, mengoordinasikan pengelolaan kebijakan industry pertahanan nasional, mengoordinasikan kerjasama internasional unuk membangun dan mengembangkan industry pertahanan nasional, 
melaksanakan pemantauan dan evaluasi pengelolaan kebijakan industry pertahanan, menyusun dan membentuk rencana induk industry pertahanan jangka Panjang, menetapkan standar produk industry pertahanan, dan menetapkan kebijakan untuk pemenuhan kebutuhan alat peralatan pertahanan dan keamanan. Dalam kaitannya dengan pemangunan kekuatan pokok pertahanan, tugas KKIP adalah melakukan sinkronisasi terhadap cetak biru industry pertahanan nasional, sehingga dapt sejalan dengan cetak biru pembangunan kekuatan pokok pertahanan dan cetak biru penelitian dan pengembangan (RDT\& E) alutsista di Indonesia. Dengan demikian, BUMN dan BUMS yang ada dapat mensinergikan dirinya agar mampu berperan dalam mendukung pengadaan alutsista untuk kebutuhan TNI di msa mendatang. BUMN Industri Pertahanan (BUMNIP) terdiri dari lima perusahaan milik negara, yaitu PT PINDAD, PT Dirgantara Indonesia, PT Penata Angkatan Laut (PAL), PT Dahana dan PT LEN. BUMN tersebut di antaranya dapat bertindak sebagai lead integrator. Di samping itu banyak juga BUMS yang bergerak dalam industry pertahanan untuk pembangunan alutsista di matra darat, laut, dan udara. Termasuk industry pertahnn nonalutsista adalah perusahaan mkanan kaleng untuk prajurit, tekstil untuk pakaian seragam, payung udara, dan peralatan perlengkapan prajurit.

Rencana induk pengembangan industry pertahanan merupakan penjabaran dari undangUndang Industri Pertahanan yang menekankan adanya pemberian insentif untuk mendorong perkembangan industry pertahanan di Indonesia. Sebelas insentif yang ditawarkan dalam UU Industri Pertahanan berupa insentif fiscal dan nonfiskal dapat dilihat pada table. Pemberian insentif ini merupakan perlakuakn khusus yang diberikan khusus untuk industry pertahanan.

\section{Insentif Industri Pertahanan Indonesia berdasarkan UU Industri Pertahanan}

\begin{tabular}{|l|l|}
\hline NO & BENTUK INSENTIF \\
\hline 1. & $\begin{array}{l}\text { Suntikan dana bagi pengembangan teknologi, dapat berupa kredit jangka Panjang } \\
\text { untuk ekspansi usaha, penyertaan modal dan proyek tahun jamak (multiyear project). }\end{array}$ \\
\hline 2. & Penggunaan produk dalam negeri. \\
\hline 3. & $\begin{array}{l}\text { Kemudahan melaksanakan perdaganan luar negeri dan bebas bea masuk untuk bahan } \\
\text { baku dan komponen. Di samping itu, perlu memberikan proteksi pada industry } \\
\text { berbasis bahan baku local. }\end{array}$ \\
\hline 4. & Pengembangan produk dilaksanakan Bersama dengan pemerintah. \\
\hline 5. & Litbang, rekayasa dan rancang bangun. \\
\hline 6. & Penggunaan sarana penelitian milik pemerintah. \\
\hline 7. & Penyiapan dan bantuan SDM termasuk Diklat \\
\hline 8. & Peningkatan Tingkat Komponen Dalam Negeri (TKDN) \\
\hline 9. & Proteksi melalui standardisasi dan sertifikasi. \\
\hline 10. & Kemudahan pemasaran di luar negeri. \\
\hline 11. & Kemudahan Hak Atas Kekayaan Intelektual (HAKI) \\
\hline
\end{tabular}


Bakrie, Connie Rahakundini, 2007, Pertahanan Negara dan Postur TNI Ideal. Yayasan Obor Indonesia, Jakarta.

Budiardjo, Miriam, 2008, Dasar-Dasar Ilmu Politik. PT Gramedia Pustaka Utama, Jakarta.

Buku Putih Indonesia 2005-2025 Tentang Penelitian, Pengembangan dan Penerapan Ilmu

Pengetahuan dan Teknologi Bidang Pertahanan dan Keamanan Tahun 2006 Kementerian Negara Riset dan Teknologi Republik Indonesia.

Buku Putih Pertahanan Indonesia Tahun 2008 Departemen Pertahanan Republik Indonesia. Buku Putih Pertahanan Indonesia Tahun 2015 Kementerian Pertahanan Republik Indonesia Buku Putih Pertahanan Negara Republik Indonesia Tahun 2003 Kementerian Pertahanan Buntoro, Kresno, 2014, Lintas Navigasi di Nusantara Indonesia. PT Raja Grafindo Persada, Jakarta.

http://idu.ac.id/index.php?option=com_content \&view=article\&id=240:unhan-indonesialaksanakan-sarasehan-akademik-qekonomi-pertahananq\&catid=37:news\&Itemid=338

Indonesia Berdaulat Bermartabat : Kompilasi Pemikiran Anggota Komisi 1 DPR RI 20092014, 2014, RMBOOKS, Jakarta.

Karima, Silmy, 2014, Membangun Kemandirian Industri Pertahanan Indonesia. Kepustakaan Populer Gramedia, Jakarta.

Keputusan Menteri Pertahanan Nomor : KEPI/1008/M/V/2017 Tentang Kebijakan Pertahanan Negara Tahun 2018

Lubis, Solly, 2014, Politik Hukum dan Kebijakan Publik (Legal Policy and Public Policy). Mandar Maju, Bandung.

Muhammad, Abdulkadir, 2004 Hukum dan Penelitian Hukum metode Penelitian Ilmu . Citra Aditya Bakti, Bandung.

Muradi, 2012, Dinamika Politik Pertahanan dan Keamanan : Memahami Masalah dan

Kebijakan Politik Pertahanan Keamanan Era Reformasi. Widya Padjadjaran, Bandung.

Nasution, Bahder Johan, 2008 Metode Penelitian Ilmu Hukum, Mandar Maju, Bandung.

Peraturan Presiden Nomor 42 Tahun 2010 Tentang Komite Kebijakan Industri Pertahanan

(KKIP)

Peraturan Presiden Republik Indonesia Nomor 59 Tahun 2013 Tentang Organisasi, Tata Kerja dan Sekretariat KKIP

Rahardjo, Satjipto, 2012, Ilmu Hukum. PT Citra Aditya Bakti, Bandung.

Risalah Rapat Dengar Pendapat (RDP) Panitia Kerja (Panja) RUU Tentang Industri Pertahanan dan Keamanan Komisi I DPR RI

Risalah Rapat Kerja Komisi I DPR RI dengan Menteri Pertahanan dan Panglima TNI Tahun Sidang 2009-2010 Masa Persidangan II Senin, 22 Februari 2010

Supriyatno, Makmur, 2014, Tentang Ilmu Pertahanan. Yayasan Pustaka Obor Indonesia, Jakarta.

Undang-undang no. 18 tahun 2002 tentang Sistem Nasional Penelitian, Pengembangan dan Penerapan Ilmu Pengetahuan dan Teknologi.

Undang-undang No.3 tahun 2002 tentang Pertahanan Negara.

Undang-Undang Nomor 16 Tahun 2012 Tentang Industri Pertahanan

WIRA Media Informasi Kementerian Pertahanan Volume 70/NOMOR 54, 2018, Kebijakan pertahanan Negara, Kementerian Pertahanan, Jakarta.

Yusgiantoro, Purnomo, 2014, Ekonomi Pertahanan : Teori dan Praktik. PT. Gramedia Pustaka Utama, Jakarta. 